\title{
ANALISIS KEMAMPUAN BERPIKIR TINGKAT TINGGI DENGAN PROGRAM TINDAK LANJUT EVALUASI HASIL BELAJAR PESERTA DIDIK MATERI TERMODINAMIKA DAN GELOMBANG DI MAN 2 SOPPENG
}

\author{
Marsiana $^{1}$, Suhardiman ${ }^{2}$, Usman $^{3}$, Fitriani Kadir $^{4}$ \\ ${ }^{1,2,3}$ UIN Alauddin Makassar, ${ }^{4}$ Universitas Muslim Maros \\ e-mail : marsianaxiiipa2@gmail.com
}

\begin{abstract}
High Level Of Ability Analysis with Follow-up Program Evaluation of Student Learning Outcomes Class XI IPA MAN 2 Soppeng. This research is a descriptive research that will analyze the thinking ability of high-level learners in solving.This study aims to find out: (1) High-level thinking ability of students of class XI IPA MAN 2 Soppeng; (2) Follow-up evaluation of the learning outcomes of students of class XI IPA MAN 2 Soppeng. The type and research design used in this research is quantitative descriptive. The results showed that the ability to think high levels in students is still relatively low. Where in this case it is shown based on the results of a high level of thinking ability test in class XI IPA that 95\% remedial with the number of learners 39 people. The form of enrichment and remedial follow-up given to learners varies depending on the indicators that have not been subdued by the learner. The results of this study are expected to provide information about students' high-level thinking ability in Thermodynamics and Wave materials for high school and can be a reference to improve students' highlevel thinking skills.
\end{abstract}

Keywords: HOTS, Hots Problem, Enrichment, Remedial.

\begin{abstract}
Abstrak: Analisis Kemampuan Berpikir Tingkat Tinggi Dengan Program Tindak Lanjut Evaluasi Hasil Belajar Peserta Didik Kelas XI IPA MAN 2 Soppeng. Penelitian ini merupakan penelitian deskriptif yang akan menganalisis kemampuan berpikir tingkat tinggi peserta didik dalam menyelesaikan soal Higher Order Thinking Skill (HOTS) dengan tindak lanjut evaluasi hasil belajar. Sesuai dengan permasalahan yang diteliti yaitu untuk mengetahui tingkat kemampuan berpikir tingkat tinggi dari peserta didik. Maka penelitian ini menggunakan analisis isi. Penelitian ini bertujuan untuk mengetahui: (1) Kemampuan berpikir tingkat tinggi peserta didik kelas XI IPA MAN 2 Soppeng; (2) Bentuk tindak lanjut evaluasi hasil belajar peserta didik kelas XI IPA MAN 2 Soppeng. Kemampuan berpikir tingkat tinggi peserta didik masih tergolong rendah. Dimana dalam hal ini ditunjukkan berdasarkan hasil tes kemampuan berpikir tingkat tinggi pada kelas XI IPA bahwa 95\% remedial dengan jumlah peserta didik 39 orang. Sedangkan $5 \%$ peserta didik lainnya telah lulus atau memenuhi standar yang nilainya lebih dari KKM. Bentuk tindak lanjut pengayaan dan remedial yang diberikan kepada peserta didik bervariasi tergantung dari banyaknya indikator yang belum dituntasi oleh peserta didik. Dua peserta didik yang diberikan tindak lanjut pengayaan dan 39 peserta didik lainnya diberikan
\end{abstract}


tindak lanjut remedial. Hasil penelitian ini diharapkan dapat memberikan informasi tentang kemampuan berpikir tingkat tinggi peserta didik pada materi Termodinamika dan Gelombang untuk SMA serta dapat menjadi bahan evaluasi bagi para pendidik/dosen untuk menerapkan pendekatan kemampuan berpikir dalam pembelajaran fisika.

Kata kunci: HOTS, Soal HOTS, Pengayaan, Remedial.

\section{PENDAHULUAN}

Pendidikan merupakan salah satu cara yang dapat membentuk seseorang menjadi pribadi yang cerdas, bermoral, dan bertanggung jawab. Dengan pendidikan, seseorang dapat mengembangkan, pengetahuan, sikap maupun keterampilan. Salah satu keberhasilan dalam meningkatkan sumber daya manusia dalam bidang pendidikan adalah peserta didik harus memiliki keterampilan berpikir tingkat tinggi yang baik, karena tujuan pokok pembelajaran pada abad ke-21 adalah mengembangkan dan meningkatkan keterampilan berpikir siswa menjadi keterampilan berpikir tingkat tinggi. Kurikulum abad ke-21 yaitu kurikulum yang terbentuk berdasarkan kebutuhan di masa depan yang menuntut peserta didik untuk memiliki kemampuan dalam memecahkan masalah, berpikir kritis, berkolaborasi dengan siswa lainnya, berkomunikasi dengan baik, dan memiliki kreativitas (Sani, 2019).

Menurut Ernawati (2017) pengalaman dalam memecahkan masalah yang sulit membutuhkan kemampuan bepikir tingkat tinggi atau higher order thingking skills (HOTS). Permendikbud No. 81 Tahun 2013 terkait dengan implementasi kurikulum 2013, menjelaskan bahwa kebutuhan kompetensi di masa yang akan datang memerlukan kemampuan berpikir yang kritis, komunikatif, dan kreatif. Ketika peserta didik memusatkan memusatkan pikirannya untuk menemukan penyelesaian tertentu dari suatu masalah maka ia sedang mengembangkan keterampilan dalam berpikir kritis (Rahayu, 2019). Dengan demikian, hal tersebut sesuai dengan karakteristik kemampuan masyarakat pada abad ke-21, yang mengidentifikasi bahwa proses pembelajaran harus mampu mengembangkan kemampuan berpikir peserta didik dalam bersaing. Kemampuan berpikir tingkat tinggi merupakan cara berpikir yang tidak hanya menerapkan kegiatan menghafal secara verbalistik, namun juga memaknai cara berpikir secara integral seperti menganalisis, mengasosiasi, dan mensintesis hingga dapat menarik kesimpulan menuju hasil pemikiran yang kreatif, dan produktif. Penelitian terdahulu dilakukan oleh Nur Faizah Akmala (2019) terkait analisis kemampuan berpikir tingkat tinggi peserta didik yaitu analisis kemampuan berpikir tingkat tinggi siswa pada materi fisika kelas X SMA di Bandar Lampung. Hasil penelitian tersebut juga sejalan dengan hasil pada penelitian yang dilakukan oleh Anggita Permatasari (2017), yaitu analisis kemampuan berpikir tingkat tinggi siswa SMA yang menunjukkan bahwa hasil rata-rata nilai peserta didik tersebut pada indikator C6 (Mencipta) rata-rata nilainya terendah sedangkan rata-rata nilai tertinggi terdapat pada indikator C4 (Menganalisis).

Berdasarkan penelitian tersebut terkait dengan kemampuan berpikir tingkat tinggi pada peserta didik dan pentingnya kemampuan berpikir tingkat tinggi yang diperlukan oleh peserta didik untuk menghadapi tantangan abad 21, peneliti mencoba untuk menganalisis kemampuan berpikir tingkat tinggi peserta didik dengan memberikan tindak lanjut dari evaluasi belajar peserta didik, yaitu remedial dan pengayaan. Penelitian ini dilakukan di salah satu sekolah yang berada di Soppeng, yaitu MAN 2 Soppeng. Berdasarkan hasil observasi pra penelitian di MAN 2 Soppeng dengan melakukan wawancara kepada guru fisika, didapatkan informasi bahwa di sekolah tersebut sudah menerapkan pembelajaran berbasis HOTS. Hal tersebut dapat dilihat dari hasil ulangan harian pada mata pelajaran fisika, sebagian besar peserta didik telah mencapai nilai $\mathrm{kkm}$. Dengan diterapkannya pembelajaran berbasis HOTS peserta didik MAN 2 Soppeng diharapkan memiliki keterampilan yang cukup baik dalam menyelesaikan soal HOTS. 
Kemudian peserta didik yang memenuhi nilai KKM atau tidak memenuhi juga menjadi masalah dalam tindak lanjut evaluasi hasil belajar peserta didik. Karena guru mata pelajaran masih kurang memperhatikan atau memperdulikan pencapaian keberhasilan peserta didik dalam pembelajaran di kelas. Hal tersebut dapat diilihat dari guru yang bersangkutan hanya mengandalkan proses pengambilan nilai MID semester UAS saja. Dengan tidak diterapkannya proses remedial dan pengayaan akan membuat peserta didik berpikir hanya sampai di situ saja tidak berpikir untuk menemukan sesuatu yang baru dari apa yang dipelajari dan membuat peserta didik tidak mengetahui kebenaran dan kekeliruan dari soal yang telah dikerjakan. Sementara itu, padahal proses remedial dan pengayaan sangatlah penting bagi peserta didik yang mempunyai kelebihan dan kekurangan tertentu dalam suatu pelajaran. Karena pembelajaran berbasis kompetensi mengharuskan pencapaian ketuntasan dalam pencapaian kompetensi untuk seluruh kompetensi dasar secara perorangan. Sehingga hal tersebut mengharuskan dilaksanakannya program remedial dan pengayaan sebagai bagian tak terpisahkan dari penerapan sistem pembelajaran yang tuntas.

Berdasarkan hal tersebut perlunya dilakukan penelitian mengenai keterampilan berpikir tingkat tinggi di MAN 2 Soppeng dimana pengukuran kemampuan tersebut dilakukan dengan pemberian soal HOTS . Juga diharapkan dengan adanya penelitian ini pendidik atau guru lebih dapat memahami betapa pentingnya program tindak lanjut evaluasi hasil belajar, yaitu remedial dan pengayaan. Maka peneliti tertarik untuk melakukan penelitian dengan judul "Analisis Kemampuan Berpikir Tingkat dengan Program Tindak Lanjut Evaluasi Hasil Belajar Peserta Didik Kelas XI IPA MAN 2 Soppeng”.

\section{METODE}

Jenis penelitian ini adalah deskriptif. Penelitian deskriptif merupakan penelitian yang dimaksudkan untuk mengumpulkan informasi mengenai status suatu gejala yang ada (Arikunto, 2010). Sesuai dengan permasalahan yang diteliti yaitu untuk mengetahui tingkat kemampuan berpikir tingkat tinggi dari peserta didik. Maka penelitian ini menggunakan analisis isi mengenai tingkat kemampuan berpikir tingkat tinggi peserta didik dengan program tindak lanjut evaluasi hasil belajar. sPopulasi dan sampel dalam penelitian ini adalah seluruh peserta didik kelas XI IPA MAN 2 Soppeng tahun ajaran 2020/2021 dengan jumlah 41 orang.

Menurut Sugiyono (2011) instrumen penelitian merupakan alat yang digunakan untuk mengukur fenomena alam maupun sosial yang diamati. Instrumen yang digunakan adalah tes kemampuan berpikir tingkat tinggi peserta didik dalam bentuk soal pilihan ganda. Adapun kisikisi instrument soal yang digunakan tertera pada Tabel1.

Tabel 1. Kisi-Kisi Instrumen soal

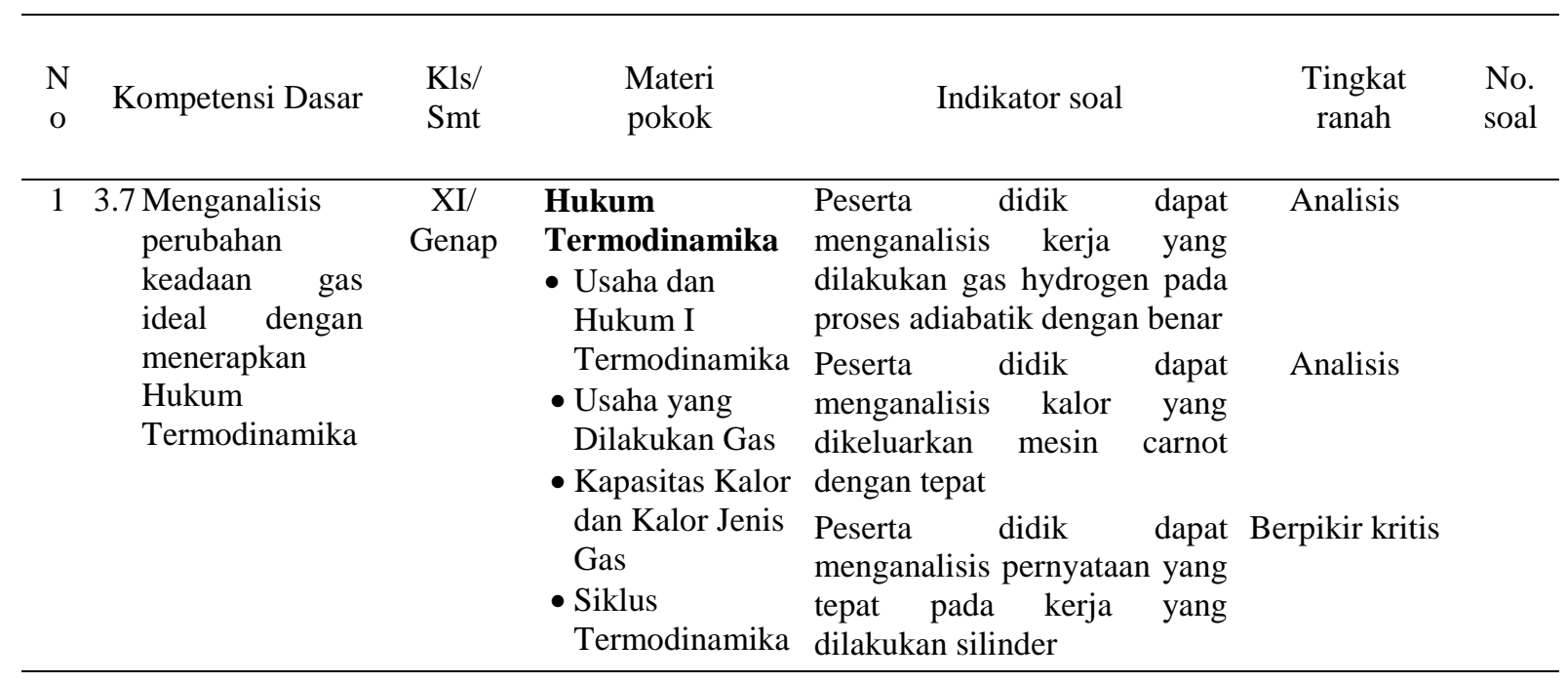


Karst : Jurnal Pendidikan Fisika dan Terapannya Volume 4 | Nomor $2 \mid 66$ p-ISSN: 2622-9641 e-ISSN: 2655-1276

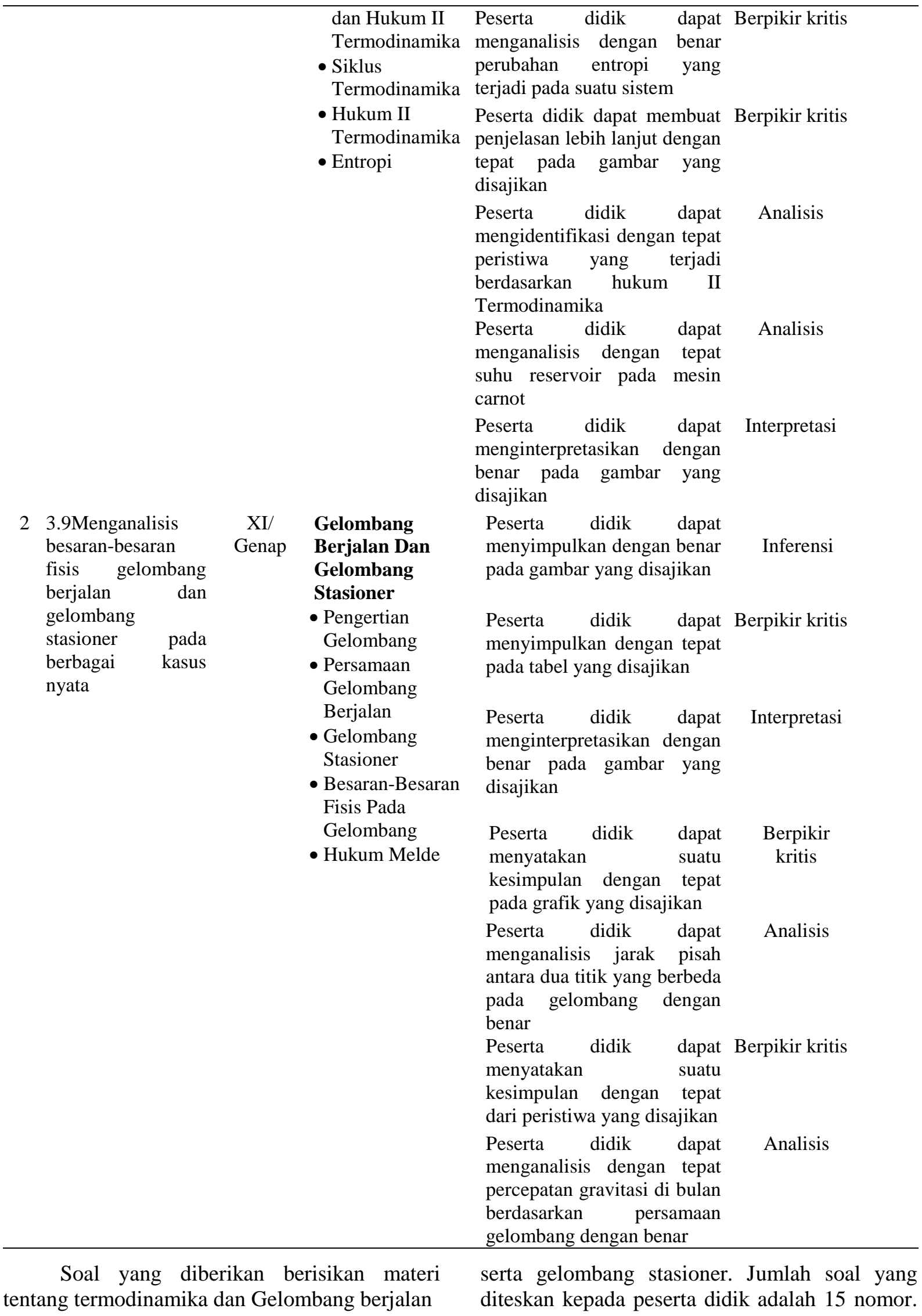


Adapun kerangka pikir untuk memudahkan alur penelitian tertera pada Gambar 1.

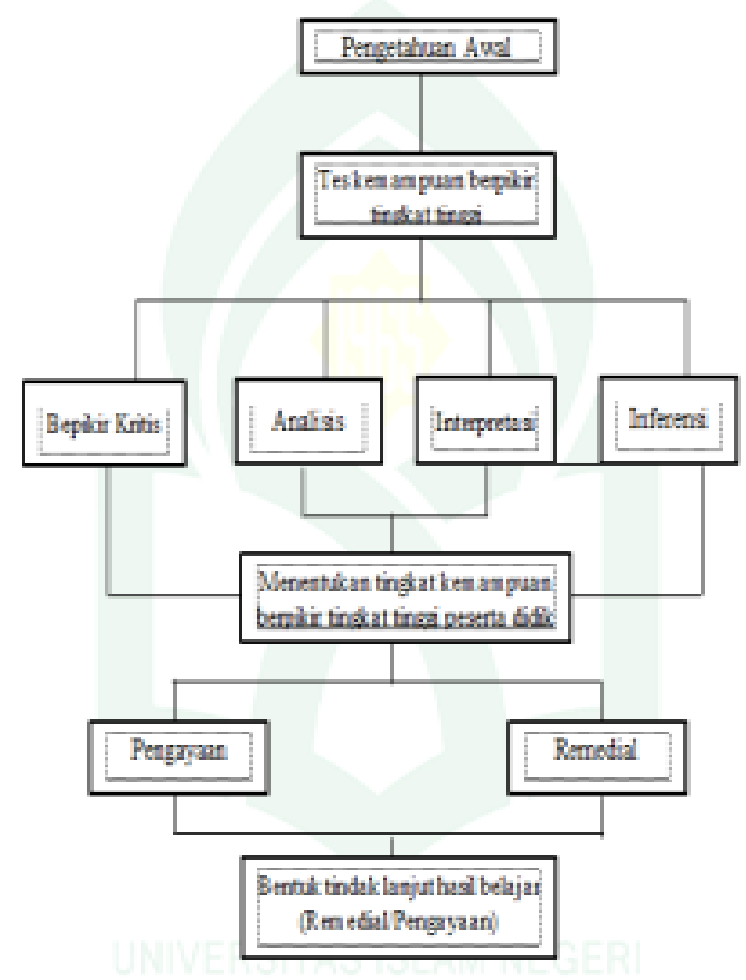

\section{Gambar 1. Kerangka Pikir}

Analisis data merupakan sebuah proses yang dilakukan untuk mengolah data yang telah diperoleh dari hasil penelitian untuk mendapatkan sebuah kesimpulan yang dapat dipertanggungjawabkan kebenarannya. Menurut Sugiyono (2012) bahwa Statistik deskriptif adalah statistik yang digunakan untuk menganalisa data dengan cara mendeskripsikan atau menggambarkan data yang telah terkumpul sebagaimana adanya tanpa bermaksud membuat kesimpulan yang berlaku untuk umum atau generalisasi.

\section{Mean skore/ skor rata-rata (x)}

Berikut ini rumus yang digunakan untuk mencari nilai rata-rata (mean) dalam (Sumanto, 2014: 34) adalah:

$$
\bar{X}=\frac{\sum X}{N}
$$

Dimana

$$
\begin{array}{ll}
\bar{X} & =\text { Rata-rata (Mean) } \\
\Sigma \mathrm{X} & =\text { Jumlah skor keseluruhan } \\
N & =\text { Jumlah individu skor }
\end{array}
$$

\section{Standar deviasi (S)}

Adapun rumus yang dugunakan untuk mencari standar deviasi menurut Syafril (2019). adalah sebagi berikut:

$$
s=\sqrt{\frac{f_{1}\left(X_{1}-x\right)^{2}}{n-1}}
$$

\section{Keterangan:}

$\mathrm{S}=$ Standar Deviasi

$\mathrm{x}=$ Mean (rata-rata)

$\mathrm{f}_{1}=$ Frekuensi yang sesuai dengan tanda kelas $\mathrm{X}_{1}$

$\mathrm{X}_{1}=$ tanda kelas interval atau nilai tengah dari kelas interval

$\mathrm{n} \quad=$ Jumlah responden

\section{Kategorisasi Penilaian}

Penilaian kemampuan berpikir tingkat tinggi dengan mengukur lima indikator, yaitu analisis, berpikir kritis, interpretasi, dan inferensi. Kategorisasi penilaian dalam penelitian ini adalah menurut Eko W (2014) tertera pada Tabel 2.

Tabel 2. Kategorisasi Penilaian

\begin{tabular}{ccc}
\hline No & Rumus & Klasifikasi \\
\hline 1 & $\bar{X}>\bar{X}_{l}+1,8 s b_{i}$ & Sangat baik \\
2 & $\bar{X}_{l}+0,6 \times s b_{i}<X \leq \bar{X}_{l}+1,8 \times s b_{i}$ & Baik \\
3 & $\bar{X}_{l}-0,6 \times s b_{i}<X \leq \bar{X}_{l}+0,6 \times s b_{i}$ & Cukup \\
4 & $\bar{X}_{l}-1,8 \times s b_{i}<X \leq \bar{X}_{l}-0,6 \times s b_{i}$ & Kurang \\
5 & $\bar{X} \leq \bar{X}_{l}-1,8 s b_{i}$ & Sangat kurang \\
\hline
\end{tabular}

Setelah dianalisis menggunaan rumus di atas maka diperoleh diagram kategorisasi . kemampuan berpikir tingkat tinggi peserta didik yang tertera pada gambar 2. 
Gambar 2. Kategorisasi Penilaian Kemampuan Berpikir Tingkat Tinggi

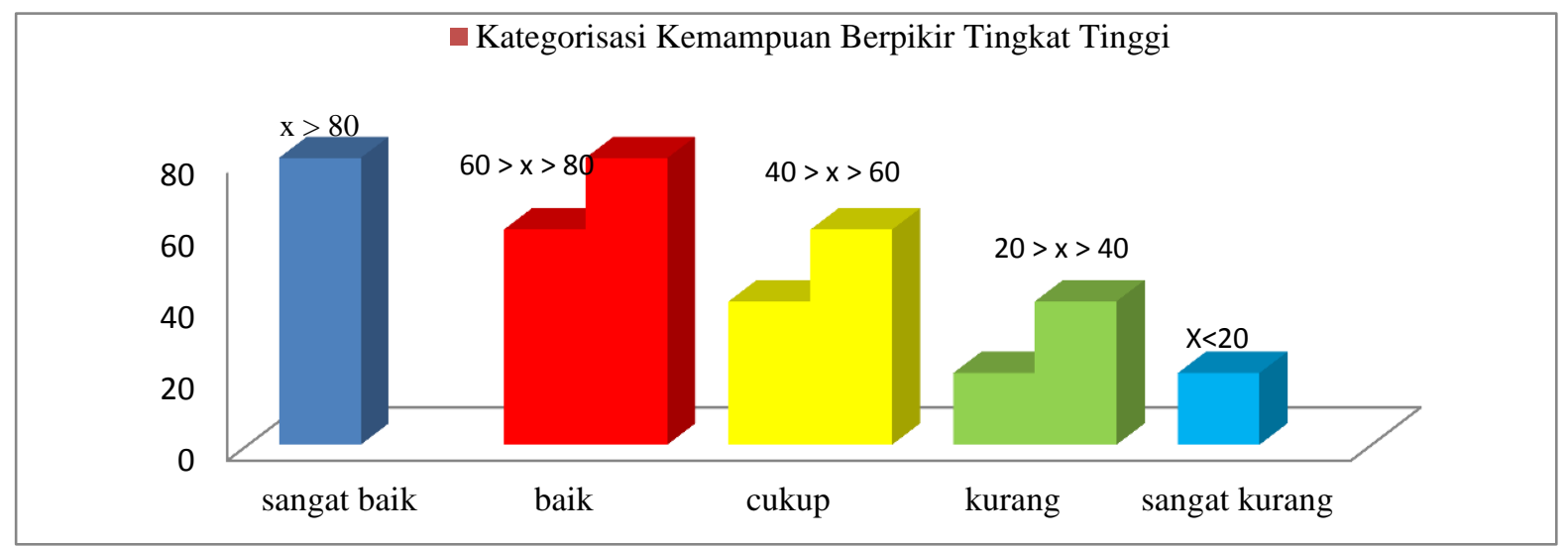

\section{HASIL DAN PEMBAHASAN}

\section{Berpikir kritis}

Setelah diperiksa dan diamati hasil tes kemampuan berpikir tingkat tinggi peserta didik kelas XI IPA, maka diperoleh data yang tertera pada
Tabel

Tabel 3. Kategorisasi Kemampuan Berpikir Tingkat Tinggi pada Indikator Berpikir Kritis

\begin{tabular}{ccccc}
\hline No & Interval & Persentase $(\%)$ & Predikat & $f$ \\
\hline 1 & $\mathrm{X}>80$ & 4,87 & sangat baik & 2 \\
2 & $60>\mathrm{x}>80$ & 0 & baik & 0 \\
3 & $40>\mathrm{x}>60$ & 85,36 & cukup & 35 \\
4 & $20>\mathrm{x}>40$ & 2,43 & kurang & 1 \\
5 & $\mathrm{x}<20$ & 7,31 & sangat kurang & 3 \\
& Total & $\mathbf{1 0 0 \%}$ & & $\mathbf{4 1}$ \\
\hline
\end{tabular}

Berdasarkan hasil analisis data kemampuan berpikir tingkat tinggi pada indikator berpikir kritis, sebanyak 2 peserta didik memperoleh kategori sangat baik dengan persentase 4,7\%, 35 peserta didik pada kategori cukup dengan persentase $85,36 \%, 1$ peserta didik pada kategori kurang dengan persentase $2,43 \%$, dan 3 peserta didik pada kategori sangat kurang dengan persentase 7,31\%. Kemampuan berpikir tingkat tinggi pada indikator berpikir kritis tertera pada Gambar 3.

Gambar 3. Diagram Kemampuan Berpikir Tingkat Tinggi pada Indikator Berpikir Kritis

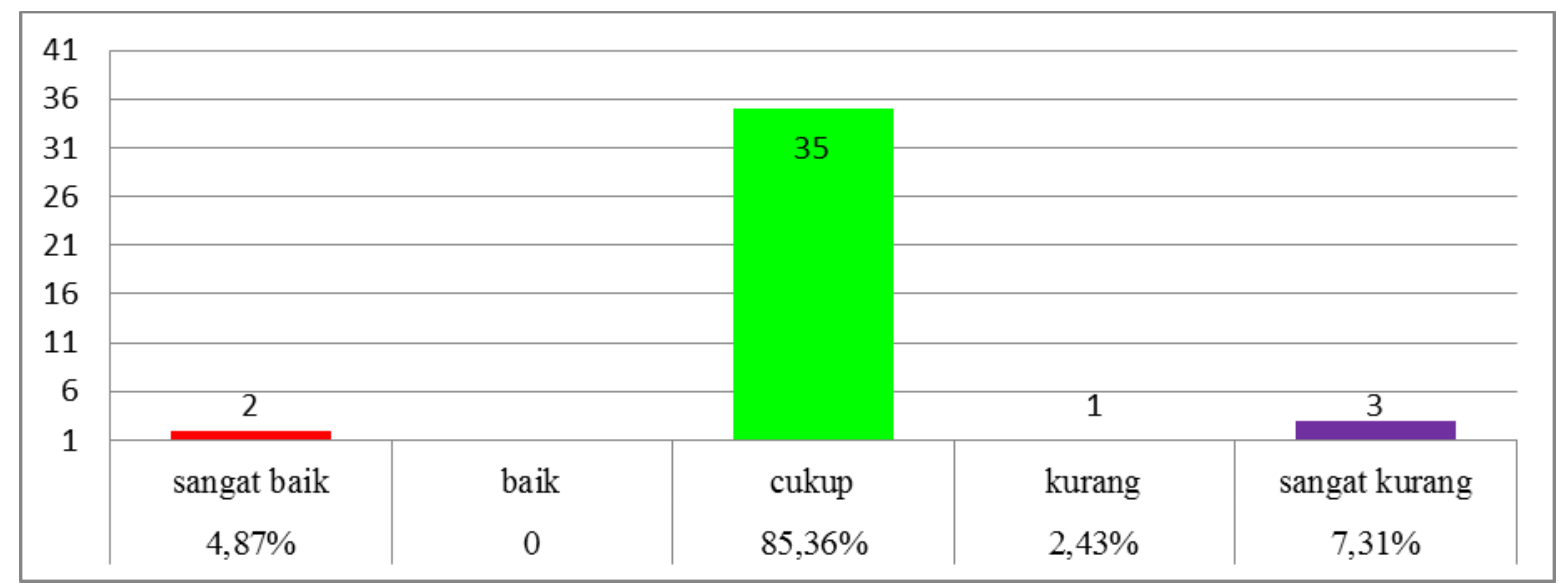


Karst : Jurnal Pendidikan Fisika dan Terapannya

Volume 4 | Nomor $2 \mid 69$

p-ISSN: 2622-9641 e-ISSN: 2655-1276

\section{Analisis}

Setelah diperiksa dan diamati hasil tes kemampuan berpikir tingkat tinggi peserta didik kelas XI IPA, maka diperoleh data yang tertera pada Tabel 4.

Tabel 4. Kategorisasi Kemampuan Berpikir Tingkat Tinggi pada Indikator Analisis

\begin{tabular}{ccccc}
\hline No & Interval & Persentase $(\%)$ & Predikat & $f$ \\
\hline 1 & $\mathrm{x}>80$ & 2,43 & sangat baik & 1 \\
2 & $60>\mathrm{x}>80$ & 9,75 & baik & 4 \\
3 & $40>\mathrm{x}>60$ & 51,21 & cukup & 20 \\
4 & $20>\mathrm{x}>40$ & 31,70 & kurang & 13 \\
5 & $\mathrm{x}<20$ & 7,31 & sangat kurang & 3 \\
& Total & $\mathbf{1 0 0 \%}$ & $\mathbf{4 1}$ \\
\hline
\end{tabular}

Berdasarkan hasil analisis data kemampuan berpikir tingkat tinggi pada indikator analisis, sebanyak 1 peserta didik memperoleh kategori sangat baik dengan persentase $2,43 \%, 4$ peserta didik pada kategori baik dengan persentase $9,75 \%, 20$ peserta didik pada kategori cukup dengan persentase $51,21 \%$, 13 peserta didik pada kategori kurang dengan persentase $31,70 \%$, dan 3 peserta didik pada kategori sangat kurang dengan persentase $7,31 \%$.

\section{Gambar 4. Diagram Kemampuan Berpikir Tingkat Tinggi pada Indikator Analisis}

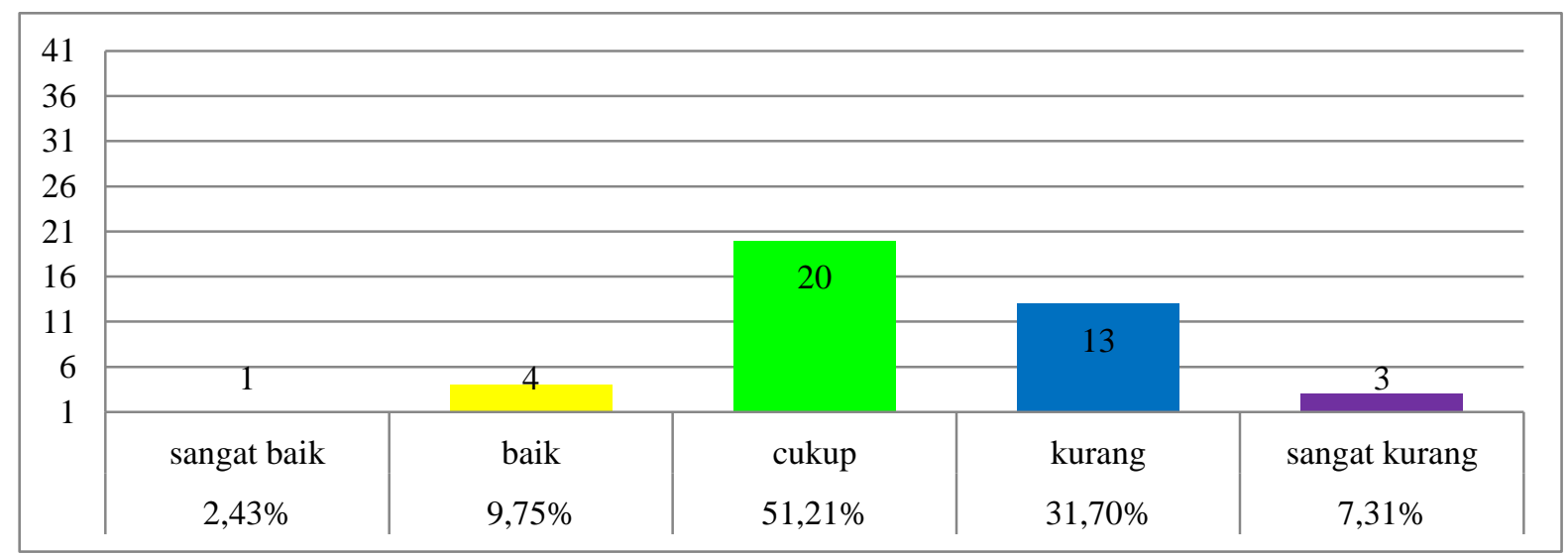

\section{Interpretasi}

Setelah diperiksa dan diamati hasil tes kemampuan berpikir tingkat tinggi peserta didik kelas XI IPA, maka diperoleh data yang tertera pada Tabel 5 .

Tabel 5. Kategorisasi Kemampuan Berpikir Tingkat Tinggi pada Indikator Interpretasi

\begin{tabular}{ccccc}
\hline No & Interval & Persentase $(\%)$ & Predikat & $f$ \\
\hline 1 & $\mathrm{x}>80$ & 2,43 & sangat baik & 1 \\
2 & $60>\mathrm{x}>80$ & 0 & baik & 0 \\
3 & $40>\mathrm{x}>60$ & 14,63 & cukup & 6 \\
4 & $20>\mathrm{x}>40$ & 0 & kurang & 0 \\
5 & $\mathrm{x}<20$ & 82,92 & sangat kurang & 34 \\
& Total & $\mathbf{1 0 0 \%}$ & & $\mathbf{4 1}$ \\
\hline
\end{tabular}

Berdasarkan hasil analisis data kemampuan berpikir tingkat tinggi pada indikator interpretasi, sebanyak 1 peserta didik memperoleh kategori sangat baik dengan persentase $2,43 \%$, tidak ada peserta didik pada kategori baik, 6 peserta didik pada kategori cukup dengan persentase 14,63\%, tidak ada peserta didik pada kategori kurang, dan 34 peserta didik pada kategori sangat kurang dengan persentase $82,92 \%$. 
Gambar 5. Diagram Kemampuan Berpikir Tingkat Tinggi pada Indikator Interpretasi

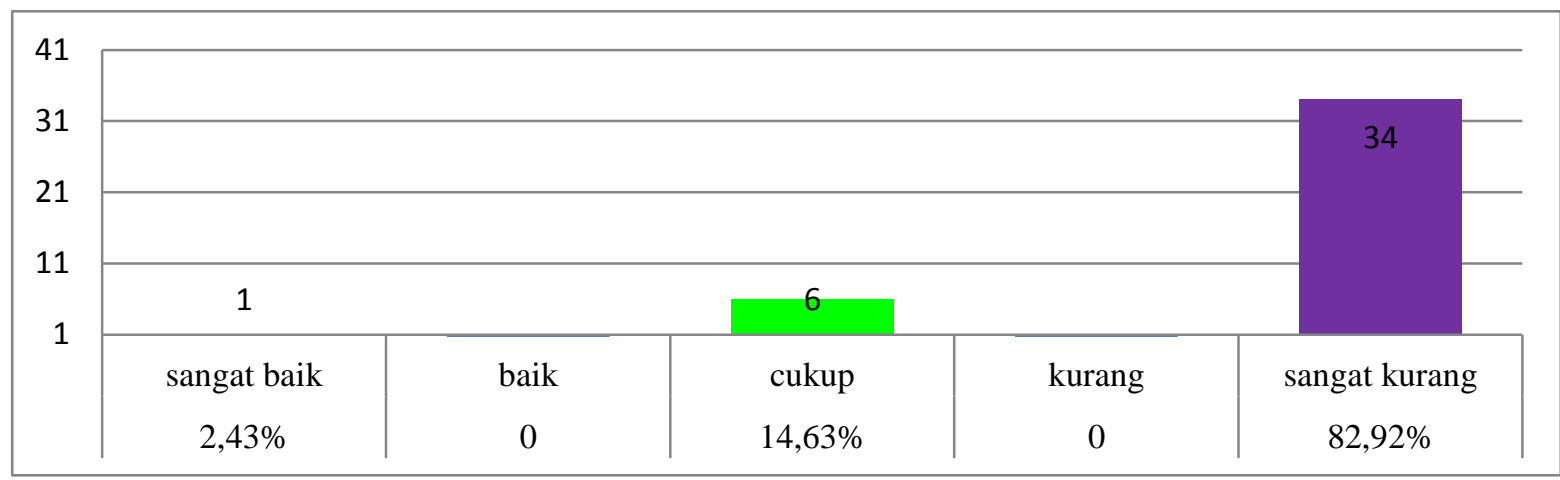

\section{Inferensi}

Setelah diperiksa dan diamati hasil tes kelas XI IPA, maka diperoleh data yang tertera kemampuan berpikir tingkat tinggi peserta didik pada

Tabel

Tabel 6. Kategorisasi Kemampuan Berpikir Tingkat Tinggi pada Indikator Inferensi

\begin{tabular}{ccccc}
\hline No & Interval & Persentase $(\%)$ & Predikat & $f$ \\
\hline 1 & $\mathrm{x}>80$ & 78,00 & sangat baik & 32 \\
2 & $60>\mathrm{x}>80$ & 0 & baik & 0 \\
3 & $40>\mathrm{x}>60$ & 0 & cukup & 0 \\
4 & $20>\mathrm{x}>40$ & 0 & kurang & 0 \\
5 & $\mathrm{x}<20$ & 21,95 & sangat kurang & 9 \\
& Total & $\mathbf{1 0 0 \%}$ & & $\mathbf{4 1}$ \\
\hline
\end{tabular}

Berdasarkan hasil analisis data kemampuan berpikir tingkat tinggi pada indikator interpretasi, sebanyak 32 peserta didik memperoleh kategori sangat baik dengan persentase $78,00 \%$, tidak ada peserta didik pada kategori baik, tidak ada peserta didik pada kategori cukup, tidak ada peserta didik pada kategori kurang, dan 9 peserta didik pada kategori sangat kurang dengan persentase $21,95 \%$.

Gambar 6. Diagram Kemampuan Berpikir Tingkat Tinggi pada Indikator Inferensi

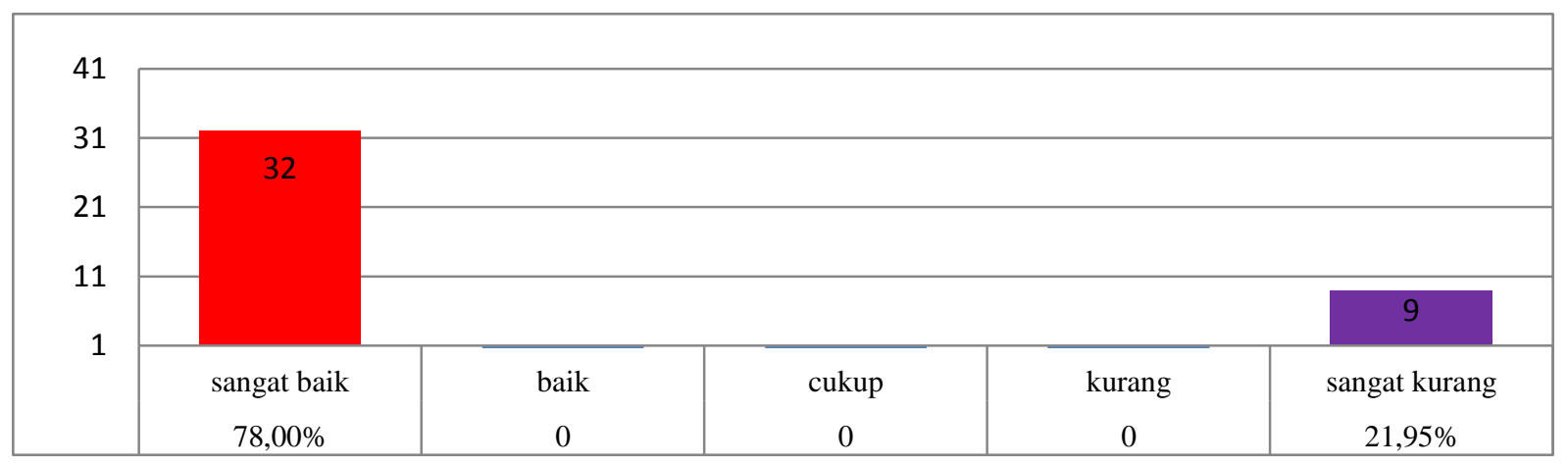

Hasil nilai rata-rata atau mean yang diperoleh peserta didik berdasarkan data statistik deskriptif adalah 78,04 yang berada pada kategori cukup. Sebanyak 32 peserta didik pada kategori sangat kurang dengan persentase sebesar $78,00 \%$.
Setelah data hasil penelitian dianalisis secara deskriptif terhadap kemampuan berpikir tingkat tinggi peserta didik, maka diperoleh nilai rata-rata kemampuan berpikir tingkat tinggi kelas XI IPA MAN 2 Soppeng dalam Tabel 7. 
Tabel 7. Statistik Deskriptif Kemampuan Berpikir Tingkat Tinggi

\begin{tabular}{lc}
\hline Statistik Deskriptif & Nilai \\
\hline Jumlah Sampul & 41 \\
Maximum & 93 \\
Minimum & 13 \\
Mean & 49,66 \\
Standard Deviation & 14.12 \\
Sample Variance & 199.38 \\
\hline
\end{tabular}

Berdasarkan tabel 7, dapat dilihat dari jumlah sampel 41 orang, nilai maksimum yang dicapai yaitu 93 dan nilai terendah yaitu 13, dan nilai rata-rata yang diperoleh sebesar 49,66. Sehingga dari tabel distribusi tersebut diperoleh hasil yang ditunjukkan pada tabel 8 .

Tabel 8. Kategorisasi Kemampuan Berpikir Tingkat Tinggi

\begin{tabular}{ccccc}
\hline No & Interval & Persentase $(\%)$ & Predikat & $f$ \\
\hline 1 & $\mathrm{X}>80$ & 0,24 & sangat baik & 1 \\
2 & $60>\mathrm{X}>80$ & 4,89 & baik & 2 \\
3 & $40>\mathrm{X}>60$ & 80,49 & cukup & 33 \\
4 & $20>\mathrm{X}>40$ & 4,89 & kurang & 2 \\
5 & $\mathrm{X}<20$ & 7,31 & sangat kurang & 3 \\
& Total & $\mathbf{1 0 0 \%}$ & & $\mathbf{4 1}$ \\
\hline
\end{tabular}

Berdasarkan tabel 8, terlihat bahwa persentase jumlah peserta didik banyak terdapat pada kategori sangat baik, yaitu sebesar $0,24 \%$ dengan jumlah peserta didik sebanyak 1 orang. Sedangkan jumlah peserta didik yang memperoleh kategori sangat kurang adalah 3 orang dengan persentase $7,31 \%$. 4,89\% pada kategori baik dengan jumlah peserta didik 2 orang, 80,49\% \% pada kategori cukup dengan jumlah peserta didik 33 orang, dan 4,89\% pada kategori cukup dengan jumlah peserta didik 2 orang.

\section{Gambar 7. Diagram Kemampuan Berpikir Tingkat Tinggi kelas XI IPA MAN 2 Soppeng}

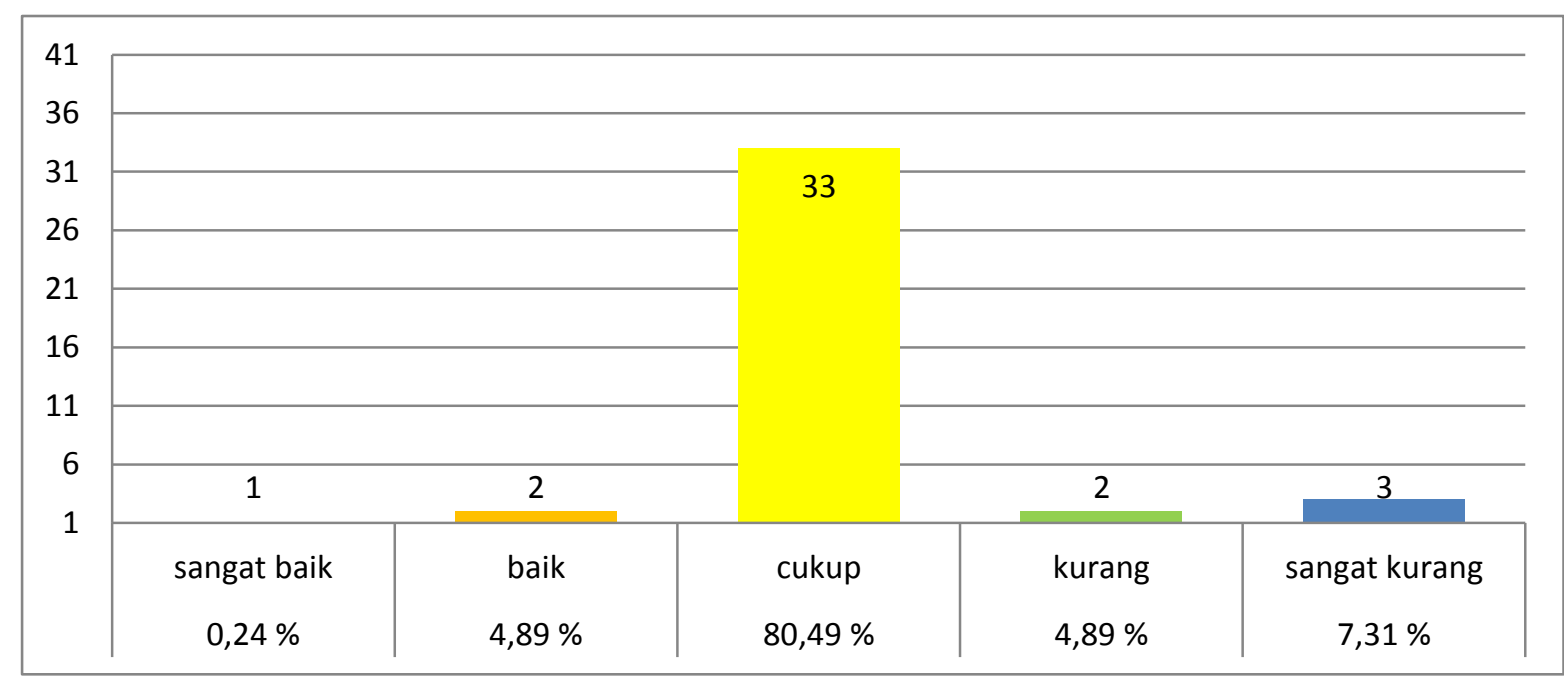

Berdasarkan tabel 8 , skor rata-rata nilai peserta didik yang diperoleh berada pada kategori cukup, yaitu pada interval $40>x>60$. Hasil nilai rata-rata atau mean yang diperoleh peserta didik berdasarkan data statistik deskriptif adalah 49,66 dengan jumlah peserta didik sebanyak 33 orang dengan persentase sebesar $80,49 \%$. 
Gambar 8. Diagram Kemampuan Berpikir Tingkat Tinggi kelas XI IPA MAN 2 Soppeng

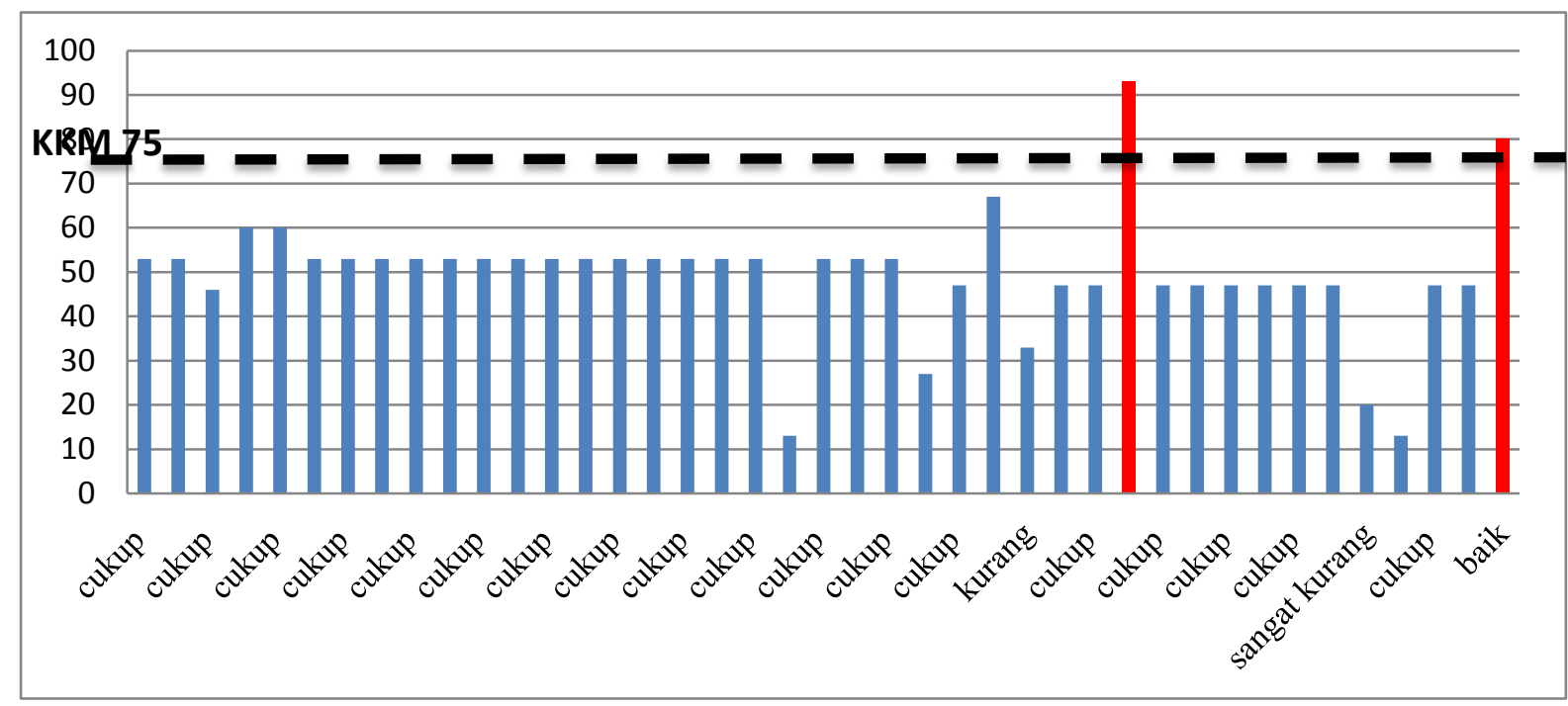

Setelah data dianalisis dan diperoleh hasil seperti gambar 5. dan 6. maka dapat diklasifikasikan tindak lanjut evaluasi hasil belajar peserta didik berdasarkan dari nilai hasil tes kemampuan berpikir tingkat tinggi peserta didik. Tindak lanjut evaluasi hasil belajar peserta didik yaitu pengayaan dan remedial. Kriteria ketuntasan minimal (KKM) yang ditentukan dari sekolah adalah 75, maka peserta didik yang memenuhi atau nilainya diatas KKM dikategorikan dalam pengayaan. Sedangkan peserta didik yang tidak memenuhi atau nilainya di bawah KKM, maka dikategorikan ke dalam remedial.

Berdasarkan gambar 5 dan 6 maka terdapat 2 peserta didik yang dikategorikan ke dalam pengayaan dengan nilai 93 dan 80. Sedangkan yang lainnya sejumlah 39 peserta didik dikategorikan ke dalam remedial karena berada dibawah standar kelulusan, yaitu 75.

\section{PEMBAHASAN}

\section{Kemampuan Berpikir Tingkat Tinggi Peserta Didik kelas XI IPA MAN 2 Soppeng}

\section{Berpikir Kritis}

Pada indikator berpikir kritis, jumlah soal yang terdapat sebanyak 7 soal yang berbeda, yaitu nomor 2, 3, 4, 5, 10, 12, dan 14 . Soal nomor urut 2 menuntut peserta didik agar dapat menganalisis kalor yang dikeluarkan pada mesin kalor carnot, soal nomor 3 agar dapat menganalisis pernyataan yang tepat pada kerja yang dilakukan silinder, soal nomor 4 agar dapat menganalisis dengan benar perubahan entropi yang terjadi pada suatu sistem, soal nomor 5 agar dapat membuat penjelasan lebih lanjut dengan tepat pada gambar yang telah disajikan, soal nomor 10 agar dapat menyimpulkan tabel yang disajikan dengan tepat, soal nomor 12 agar dapat menyatakan suatu kesimpulan dengan tepat dari grafik yang disajikan, dan soal nomor 14 agar dapat menyatakan suatu kesimpulan dengan tepat dari peristiwa yang disajikan.
Menurut Murti dalam jurnal Nugraha,dkk (2017) bahwa ciri peserta didik yang memiliki keterampilan berpikir kritis adalah dapat menarik kesimpulan dan solusi dengan alasan yang kuat. Berdasarkan hasil data penelitian yang telah dianalisis, sebagian besar nilai peserta berada pada kategori cukup. Karena masih banyak peserta didik yang belum dapat menarik kesimpulan dan solusi. Hal tersebut dapat dikatakan bahwa kemampuan berpikir kritis peserta didik kelas XI IPA MAN 2 Soppeng masih lemah. Sesuai juga dengan hasil penelitian yang dilakukan oleh Siregar, dkk (2018) bahwa salah satu permasalahan yang dialami peserta didik dalam menghadapi soal berpikir kritis adalah masih lemahnya peserta didik dalam memahami masalah. Ketidakmampuan memahami masalah dalam menghadapi soal dapat membuat peserta didik tidak dapat merancang strategi penyelesaian masalah dengan tepat. Sehingga sebagian besar peserta didik memperoleh nilai pada kategori cukup dengan rentang nilai 40-60. 


\section{Analisis}

Pada indikator analisis, jumlah soal yang terdapat sebanyak 5 soal yang berbeda, yaitu nomor $1,6,7,13$, dan 15 . Soal nomor urut 1 menuntut peserta didik agar dapat menganalisis kerja yang dilakukan gas hydrogen pada proses adiabatic dengan benar, soal nomor 6 agar apat mengidentifikasi dengan tepat peristiwa yang terjadi berdasarkan hukum II termodinamika, soal nomor 7 agar dapat meganalisis dengan tepat suhu reservoir pada mesin carnot, soal nomor 13 agar dapat menganalisis jarak pisah antara dua titik yang berbeda pada sebuah gelombang dengan benar, dan soal nomor 15 agar dapat menganalisis dengan tepat gravitasi bulan berdasarkan persamaan gelombang.

Menurut Kurniati, dkk (2016) bahwa kemampuan analisis berkaitan dengan kemampuan identifikasi ide utama soal, menganalisis argument, serta membandingkan dan mengontraskan hal yang diketahui. Peserta didik ber level HOTS sedang mampu mengidentifikasi ide utama dengan menyatakan hal yang diketahui dan ditanya pada soal dengan jelas, ringkas, dan tepat. Berdasarkan hasil data penelitian yang telah dianalisis, diperoleh bahwa pada indikator analisis nilai peserta didik ratarata berada pada kategori cukup dengan jumlah peserta didik sebanyak 20 orang. Hal tersebut terjadi karena masih banyak peserta didik yang belum mampu mengidentifikasi dan menganalisis soal dengan baik. Sehingga dapat dikatakan tahap analisis peserta didik masih lemah tetapi di atas lebih baik dari indikator berpikir kritis.

\section{Interpretasi}

Pada indikator interpretasi, jumlah soal yang terdapat sebanyak 2 soal yang berbeda, yaitu nomor 8 dan 11. Soal nomor urut 8 menuntut peserta didik agar dapat menginterpretasikan grafik yang disajikan dengan benar, dan soal nomor 11 agar dapat menginterpretasikan gambar dengan benar pada gambar yang disajikan.

Pentingnya pemahaman representasi grafik menurut Subali, dkk (2015) bahwa mampu memberikan informasi kuantitatif yang mudah dipahami. Berdasarkan hasil data penelitian yang telah dianalisis, bahwa rata-rata nilai peserta didik berada pada kategori sangat kurang. Dapat dikatakan bahwa kemampuan interpretasi peserta didik masih kurang dan lemah. Sesuai dengan penelitian Subali, dkk (2015) yang menyatakan bahwa kemampuan interpretasi merupakan salah satu kemampuan yang sulit bagi peserta didik karena kemampuan tersebut berkaitan dengan kemampuan ruang, logika, dan matematika. Agar kemampuan interpretasi baik, maka ketiga kemampuan tersebut harus optimal dikuasai oleh peserta didik.

\section{Inferensi}

Pada indikator inferensi, jumlah soal yang terdapat sebanyak 1soal yang, yaitu nomor 9 . Soal nomor urut 9 menuntut peserta didik agar dapat menyimpulkan dengan benar pada gambar yang disajikan. Menurut Facion dalam jurnal Wahyuni, dkk (2015) inferensi adalah perpindahan yang kita buat dari alasan hingga kesimpulan. Kemampuan nferensi dalam menyimpulkan gambar pada peserta didik sudah baik karena berdasarkan hasil data penelitian yang telah dianalisis, bahwa terdapat 32 peserta didik yang memperoleh nilai pada kategori sangat baik. Meskipun terdapat 9 orang yang belum bisa atau masih lemah dalam menyimpulkan suatu gambar.

\section{Tindak Lanjut Evaluasi Hasil Belajar Peserta Didik kelas XI IPA MAN 2 Soppeng}

Tindak lanjut evaluasi hasil belajar pada peserta didik adalah pengayaan dan remedial. Pengayaan dan remedial ditentukan berdasarkan dari KKM. Apabila nilai peserta didik sama atau diatas nilai KKM maka dikategorikan pengayaan. Sedangkan jika dibawah KKM maka dikategorikan remedial. Berdasarkan nilai yang diperoleh peserta didik setelah dites, hanya ada 2 peserta didik yang nilainya lebih dari nilai KKM yang ditentukan. Sedangkan 39 peserta didik lainnya nilainya kurang dari tetapan nilai KKM.

Untuk peserta didik yang dikategorikan dalam pengayaan, bentuk tindak lanjut dari pengayaan yang akan diberikan adalah belajar kelompok, Pemadatan kurikulum, dan belajar mandiri (Direktorat Jenderal Pendidikan Dasar dan Menengah

Kementerian Pendidikan dan Kebudayaan, 2015: 44) Belajar kelompok diberikan kepada 
peserta didik yang melakukan pengayaan dimaksudkan agar mereka dapat membimbing atau mengajar teman lainnya yang remedial dan belajar kelompok sesama peserta didik yang mengikuti pengayaan untuk belajar materi baru ang belum diketahui (pemadatan kurikulum). Serta belajar mandiri agar peserta didik dapat dengan mandiri belajar sesuatu yang diminati.

Peserta didik yang dikategorikan dalam remedial diberikan tindak lanjut dalam dua kelompok. Kelompok yang pertama adalah peserta didik yang mendapat skor nilai $46,66-$ 66,66 dengan jumlah peserta didik sebanyak 34 orang. Bentuk tindak lanjut remedial yang diberikan adalah pemberian tugas tambahan, Pemberian tugas-tugas latihan secara khusus, belajar kelompok dengan bimbingan siswa yang telah tuntas belajarnya, dan pembelajaran ulang dengan metode atau model yang berbeda. Pemberian tugas tambahan, yaitu, dengan mengerjakan kembali soal yang telah diberikan, kemudian berdiskusi dengan temannya dalam pembelajaran kelompok yang dimbimbing oleh teman lain yang tidak mengikuti remedial (Arnie Fajar, 2004). Pemberian tugas-tugas secara khusus. Tugas-tugas tersebut perlu diperbanyak agar peserta didik tidak mengalami kesulitan dalam mengerjakan tes akhir. Peserta didik perlu diberi pelatihan intensif untuk membantu menguasai kompetensi yang akan dicapai. Serta Pembelajaran ulang dilakukan karena sebagian besar peserta didik belum mencapai ketuntasan belajar atau mengalami kesulitan belajar. Pendidik perlu memberikan penjelasan kembali dengan menggunakan metode dan/atau media yang lebih tepat

Kelompok yang kedua adalah peserta didik yang mendapat skor nilai 33,33-13,33 dengan jumlah peserta didik sebanyak 5 orang. Bentuk tindak lanjut remedial yang diberikan adalah Pemanfaatan tutor sebaya, Pemberian bimbingan secara khusus, dan belajar kelompok dengan bimbingan guru. Tutor sebaya adalah teman sekelas atau kakak kelas yang memiliki kecepatan belajar lebih. Mereka perlu dimanfaatkan untuk memberikan tutorial kepada rekan atau adik kelas yang mengalami kesulitan belajar. Melalui tutor sebaya diharapkan peserta didik yang mengalami kesulitan belajar akan lebih terbuka dan akrab. Pemberian bimbingan perorangan adalah implikasi peran pendidik sebagai tutor. Sistem tutorial dilaksanakan karena terdapat 5 peserta didik belum berhasil mencapai ketuntasan dalam pembelajaran. Serta melakukan belajar kelompok dengan bimbingan guru agar peserta didik dapat lebih memahami dan bertanya langsung kepada guru terhadapa apa yang belum dimengerti dan dipahami.

Pemberian bentuk tindak lanjut dari hasil belajar peserta didik dimaksudkan untuk agar peserta didik dapat memahami apa yang belum dikuasai atau diketahui untuk dipelajari kembali agar dapat dituntaskan dan memperbaiki atau mengubah cara belajarnya kearah yang lebih baik serta mengembangkan potensi secara optimal, salah satu kegiatan pengayaan yaitu memberikan materi tambahan, beban tambahan atau tugas individu yang bertujuan untuk memperluas kompetensi yang telah dicapai (Sukiman, 2012).

\section{KESIMPULAN}

Berdasarkan hasil penelitian dan pembahasan yang telah dipaparkan pada bab sebelumnya, maka dapat ditarik kesimpulan bahwa, kemampuan berpikir tingkat tinggi pada peserta didik kelas XI IPA MAN 2 Soppeng untuk indikator berpikir kritis masih lemah karena sebagian besar memperoleh nilai pada kategori cukup dengan rentang nilai 40-60. Untuk kemampuan berpikir tingkat tinggi pada peserta didik kelas XI IPA MAN 2 Soppeng untuk indikator analisis masih karena nilai peserta didik rata-rata berada pada kategori cukup dengan jumlah peserta didik sebanyak 20 orang. Sedangkan kemampuan berpikir tingkat tinggi pada peserta didik kelas XI IPA MAN 2 Soppeng untuk indikator interpretasi bahwa ratarata nilai peserta didik berada pada kategori sangat kurang. Dapat dikatakan bahwa kemampuan interpretasi peserta didik masih kurang dan lemah. Serta kemampuan berpikir tingkat tinggi pada peserta didik kelas XI IPA MAN 2 Soppeng untuk indikator inferensi dalam menyimpulkan gambar sudah baik karena berdasarkan hasil data penelitian yang telah dianalisis terdapat 32 peserta didik yang memperoleh nilai pada kategori sangat baik.

Bentuk tindak lanjut pengayaan dan remedial yang diberikan kepada peserta didik bervariasi tergantung dari banyaknya indikator yang belum dituntasi oleh peserta didik. 2 
Karst : Jurnal Pendidikan Fisika dan Terapannya Volume 4 | Nomor $2 \mid 75$ p-ISSN: 2622-9641 e-ISSN: 2655-1276

peserta didik yang diberikan tindak lanjut pengayaan dan 39 peserta didik lainnya diberikan tindak lanjut remedial.

\section{DAFTAR PUSTAKA}

Arikunto, S. 2010. Prosedur penelitian. Jakarta : Rineka Cipta.

Arnie Fajar. 2004. Portofolio Dalam Pembelajaran IPS. Bandung: Pt. Remaja Rosdakarya.

Bambang Subali. 2010. Penilaian, Evaluasi dan Remediasi Pembelajaran.Yogyakarta:UNY Pers

Direktorat Pembinaan SMA. 2015. Penyusunan soal higher order thinking skill's sekolah menengah atas. Jakarta: Direktorat jendral pendidikan menengah kementerian pendidikan dan kebudayaan

Ernawati, L. Pengembangan High Order Thinking (HOT) Melalui Metode Pembelajaran Mind Banking dalam Pendidikan Agama Islam. Lamongan Darul Ulum Islamic Univercity. 2017.

Kurniati, Harimukti, dan Asiyah.2016. Kemampuan Berpikir Tingkat Tinggi Siswa SMP Di Kabupaten Jember dalam Menyelesaikan Soal Berstandar Pisa. Jurnal Penelitian dan Evaluasi Pendidikan :153

Nugraha, Suyitno, dan Susilaningsih. Analisis Kemampuan Berpikir Kritis dari KeterampilanProses Sains dan Motivasi Belajar Melalui Model PBL. Prodi Pendidikan Dasar, Pascasarjana, Universitas Negeri Semarang, Indonesia. 2017. h 40

Rahayu, Chici, dan Festiyed. 2019. Validitas Perangkat Pembelajaran Fisika SMA Berbasis model pembelajaran Generatif dengan Pendekatan Oen Ended Problem untuk Menstimulus Keterampilan Berpikir Kritis Peserta didik. Jurnal Pendidikan Fisika, Makassar: Universitas Islam Negeri Alauddin Makassar. Vol.7 No.1.

Siregar, Darhim, dan Endang. Analisis Kesulitan Siswa SMP menghadapi Soal Berpikir Kritis dan Kreatif Matematika. Pasundan Journal of Research in Mathematics Learning and Education . volume 3 no 2. 2018. h 90-91

Sani, R.A. 2019. Pembelajaran berbasis HOTS (Higher Order Thingking Skiils). Tanggerang: TSmart.

Subali, dkk. 2015. Pengembangan Desain Pembelajaran Sains Berbasis Kearifan Lokal Untuk Mengembangkan Karakter Siswa Sekolah Dasar. Jurnal Manajemen Pendidikan. Vol.9.no.1

Sugiyono. 2014. Metode Penelitian Pendidikan: Pendekatan Kuantitatif, Kualitatif, dan R\&D. Bandung: Alfabeta.

Sukiman. 2012. Pengembangan Sistem Evaluasi. Yogyakarta: Insan Madani

Syafril. Statistik Pendidikan. Jakarta: Prenadamedia Group, 2019

Wahyuni, Sudarisman, dan Sugiyarto. 2015. Efektivitas Implementasi Pembelajaran Model Problem Based Learning (PBL) Diintegrasikan dengan Predict-ObserveExplain (POE) Terhadap Prestasi Belajar Siswa Ditinjau dari Kreativitas dan Kemampuan Inferensi Siswa. Jurnal Inkuiri. 2015

$\mathrm{h}$

47-62. 